\title{
José Antônio de Camargo Rodrigues de Souza (1949-2017)
}

Na manhã do dia 13 de setembro de 2017 faleceu em Goiânia, Brasil, o Professor José Antônio de Camargo Rodrigues de Souza. A sua morte repentina interrompeu diversos trabalhos de investigação em colaboração internacional que tinha em curso e uma intensa atividade de publicação, de participação académica e de tradução, que marcou profundamente os estudos em português sobre o pensamento político medieval. O Professor Camargo de Souza foi professor sucessivamente nas universidades do Amazonas, de Brasília, de Mato Grosso, de Goiás, universidade federal onde se aposentou em 1998. Na atualidade e desde há alguns anos era investigador integrado do Instituto de Filosofia da Universidade do Porto, onde deu forte impulso à investigação e traduções sobre filosofia política medieval, colaborando regularmente também em seminários do Mestrado em Filosofia - na área de Filosofia Medieval.

O seu percurso de formação inclui a conclusão da Licenciatura em Filosofia pela Universidade de Mogi das Cruzes (1971), o Mestrado em História Social - História Medieval, pela Universidade de São Paulo (dissertação: O conceito de 'Plenitudo Potestatis' na Filosofia Politica de Guilherme de Ockham, em 1975), o doutoramento em Ciências Humanas - História Social pela Universidade de São Paulo (tese: A contibuição Filosófico-Politica de Guilherme de Ockham ao Conceito de Poder Civil, em 1980), um segundo doutoramento em Filosofia, especialidade História da Filosofia e da Cultura Portuguesa, pela Universidade Nova de Lisboa (tese: O pensamento social de Santo Antônio, em 2001). O reconhecimento e méritos da longa atividade académica ultrapassaram largamente o seu país. Ao longo de toda a carreira académica manteve uma regular colaboração com colegas do vasto mundo ibero-americano, nomeadamente de Barcelona, Buenos Aires, Coimbra, Covilhã, Lisboa, Madrid, Porto, Porto Alegre, Salamanca, Zaragoza, etc. Nas universidades destas cidades proferiu conferências e dirigiu seminários ou publicou os seus estudos e obras. De entre as suas mais recentes participações públicas deve ser assinalada a comunicação plenária convidada que proferiu no VII Congresso da SOFIME - De relatione, em Barcelona, em novembro de 2016, sobre "As relações de poder no Debate entre um clérigo e um soldado do rei”, texto anónimo do início do século XIV que também traduziu para português.

A atividade associativa que Camargo de Souza desenvolveu no Brasil foi de primeira importância. A fundação da Comissão Brasileira de Filosofia Medieval, cujas origens remontam à X semana de Filosofia da Universidade de Brasília dedicada à Filosofia Medieval e que, sob a sua organização, decorreu em setembro de 1982. Foi o primeiro presidente desta Comissão e organizou os seus três primeiros encontros, dando um impulso definitivo na consolidação e reconhecimento da Filosofia Medieval como área de estudos no Brasil (cf. «Comissão Brasileira de Filosofia Medieval - 20 Anos», Veritas, 46.3, 2001, pp. 357-378). A par da atividade que desenvolveu com outros professores da mesma geração, onde há a destacar Luis Alberto de Boni, Carlos Arthur Ribeiro do Nascimento, João Lupi, a Comissão Brasileira de Filosofia Medieval instituiu uma dinâmica de discussão e publicação académica que contribuiu para a qualificação e a projeção internacional de que a medievística filosófica brasileira agora desfruta. 
Como exemplo do trabalho de colaboração que desenvolveu com colegas de vários países, destaque-se o volume de estudos editado por José António Camargo de Souza e Bernardo Bayona Aznar (org.), Iglesia y Estado: Teorías políticas y relaciones de poder en tiempo de Bonifacio VIII y Juan XXII, Prensas Universitarias de Zaragoza, 2016, que teve edição simultânea em português em Idem (coord.), Igreja e Estado: Teorias Políticas e Relações de Poder no Tempo de Bonifácio VIII e João XXII, Aletheia-Associação Científica e Cultural, Braga, 2016. Esta obra fora antecedida por uma outra pelos mesmos organizadores: Doctrinas y relaciones de poder en el Cisma de Occidente y en la época conciliar (1378-1449), Prensas Universitarias de Zaragoza, 2013. Entre as suas obras em colaboração é também de salientar a que publicou com João Morais Barbosa, Professor da Universidade Nova de Lisboa, O Reino de Deus e o reino dos Homens As relações entre os poderes espiritual e temporal na Baixa Idade Média: da Reforma Gregoriana a João Quidort, Porto Alegre, EDIPUCRS, 1997. Entre os seus livros individuais mais importantes encontram-se: As relações de poder na Idade Média Tardia: Marsílio de Pádua, Álvaro Pais O. Min. e Guilherme de Ockham O. Min. Porto Alegre, EST Edições, 2010; O Pensamento Social de Santo Antônio, Porto Alegre, EDIPUCRS, 2001; O Reino e o Sacerdócio O Pensamento Político na Alta Idade Média, Porto Alegre, EDIPUCRS, 1995.

É particularmente notável o seu trabalho de tradução de obras políticas medievais abrangendo autores como Pedro de João Olivi (Três textos teológico-políticos sobre o poder do Romano Pontífice, Porto 2013), Tiago de Viterbo (Sobre o governo cristão, Famalicão 2012), Marsílio de Pádua ( $O$ defensor da paz, Petrópolis, 1997; Defensor menor e Sobre a translação do império, Petrópolis, 1991), Guilherme de Ockham (Terceira Parte do Diálogo, Famalicão 2012; Oito Questões sobre o poder do papa, Porto Alegre 2002; Sobre os poderes dos imperadores e dos papas e Consulta sobre uma questão matrimonial, Porto Alegre 1998), Francisco de Meyrones, Agostinho de Ancona, Bartolomeu de Lucca, Egas de Viseu e diversos textos anónimos (Antes que houvesse clérigos; Debate entre um clérigo e um soldado do rei; A questão sobre ambas as partes; entre outros). Para além dos estudos que também dedicou a estes autores, em revistas nacionais e estrangeiras, obras coletivas ou atas de congressos, publicou ainda sobre o pensamento político de Bernardo de Claraval, Tomás de Aquino, João Duns Escoto, Miguel de Cesena, Álvaro Pais, Jonas de Orléans.

Os estudos publicados e as múltiplas traduções configuram um programa de investigação prosseguido com pertinácia e um ritmo de trabalho pontualíssimo, com o qual procurou dissecar e explicitar as circunstâncias históricas e os argumentos de todas as partes no longo debate medieval sobre a questão política das relações de poder, principalmente em autores e textos dos séculos XIII e XIV, mas sem ignorar o seus antecedentes e as suas consequências. Sobre estes mesmos temas, autores e textos orientou diversas dissertações de mestrado e de doutoramento, quer em Filosofia, quer em História.

O desaparecimento do Professor José Antônio de Camargo Rodrigues de Souza deixa um insuperável sentimento de saudade e de perda entre seus antigos estudantes, orientandos, amigos e familiares. Os seus discípulos da Universidade Federal de Goiás estão a preparar uma homenagem internacional que será publicada em 2018.

JOSÉ MEIRINHOS

Universidade do Porto 